Kateryna Kraus,

Ph.D., Associate Professor of the Department of Commerce Activities and Entrepreneurship, Poltava University of Economics and Trade (Poltava, Ukraine)

\title{
INNOVATIVE HABS AS A PLATFORM OF ECONOMIC GROWTH: FOREIGN EXPERIENCE AND NEW OPPORTUNITIES FOR UKRAINE
}

General features of modern innovative clusters in the world are described in the article. The essence of innovative hub is found and main directions of its activity at the present stage of economic development are considered. A number of institutions that promote innovative development of hubs are discovered. The place and the role of modern hub-studios, hub-centers, hub-clusters and hub-associations in countries of Western Europe are generalized. Key success factors of the activity of network of centers support for innovations and entrepreneurship (iHUB) in Ukraine are investigated, and its main international partners, objectives and directions of activity are found. Prospects of the creating of border clusters in Ukraine are considered and substantiated. The activity of innovative building cluster in Poltava region is researched and its participants, key objectives and constraints of development are found.

Keywords: innovative hub, cluster, institutes of innovative development, hub-studio, hub-center, hubassociation, building cluster.

DOI: $10.21272 / \mathrm{mmi} .2017 .2-18$

Problem statement. Cluster model today is one of the most effective forms of achieving of competitive advantages and consensus of interests of business, state and public organizations for the development and introduction of innovations. Concepts of creation of innovative clusters are fairly diverse.

For example, in Canada, Spain and Germany are innovative systems; in Belgium, Netherlands, Norway, the USA, Switzerland are industrial-innovative networks and their interaction on the basis of cooperation; in Denmark are resource zones; in Italy, Finland are intersectoral knowledge flows; in the UK are regional innovative systems [13; 14].

In Ukraine, despite the strengthening of market principles in the economy, clustering of economic entities, whose activity is based on innovations, has not received a proper distribution yet. No attention is paid to issues of structure of basic models of clustering of the economy and effective interaction between institutions of innovative infrastructure.

However, justification of the model of clustering and proper construction of innovative infrastructure and institutional support of innovatization of the economy largely depend the commercial success of the business entities, both in domestic and foreign markets of new technologies/products. Therefore solving this problem is priority for Ukraine's economy, since it would accelerate its innovatization and innovative glocalization [5].

Review of recent publications. Investigation of features, problems and prospects of the activity of modern innovative hubs in the world devoted to works of many Ukrainian and foreign scientists. Theoretical and practical aspects of the development of innovative hubs and clusters have laid the authors such as J. Youtie and Ph. Shapira [15], G. Gorzka [12], E. Baark and Sh. Naubahar [11] and others.

Russian experience of creation innovative hubs is reflected in the works of V. Vasilyev and $\mathrm{N}$. Toyvonenko [10]. In Ukraine, despite the development of the market principles of economic activity and activation of integration processes in the country, creation of innovative hubs and clusters have not acquired the proper distribution, but for separate issues and problems of their activity in Ukraine dedicated scientific works of Ukrainian researchers as S. Bila and Ya. Zhalilo [4], V. Vlasenko [2], M. Dombrowskyi [3], N. Kraus [6, 7, 9], etc.

Unresolved issues. However, in works of these authors is not enough given attention to questions 
of comprehensive study of foreign experience and practice of establishing and operating conditions of innovative hubs in our days. Moreover, requires additional evaluation and substantiation the opportunity to "transfer" foreign experience of the activity successful innovative hubs of the world to practice of management in Ukraine. In this regard, it is necessary to identify key conditions and determinants of functioning of foreign innovative hubs and determine their practical value for the economic development of Ukraine, taking into account the specifics of the activity of Ukrainian business structures and relatively low investment attractiveness of the national economy.

These factors are serious barriers to economic development of Ukraine today, so they can not be ignored, given the importance of innovative development of the country in the context of integration processes. That is why chosen theme of scientific research is topical to the current stage of economic development of Ukraine.

The aim of this research is generalization of the characteristics and substantiation of expediency of the creation of innovative hubs and clusters in Ukraine. Practical output of the results consists in the discovered success factors of activity of modern innovative hubs in the world and proved necessity of their practical application in practice in Ukraine in order to create new opportunities and prospects of innovative development of the country.

Basic material. Innovative cluster systems are characterized by common features, including: stability of strategic economic ties within cluster system, including its regional, intrastate and international relations; creating by participants of cluster noncommercial association, voluntary of entering into it, existence of coordinating organization and site; long-term coordination of interaction between members of cluster system within its national and intra development programs, innovative and investment projects [3, c. $242 ; 8$, c. 30$]$.

It is noteworthy that in this model, the driving force, the basic core, we offer consider an innovative hub. An innovative hub is a kind of industrial-scientific-innovative complex that is based on knowledge [6, c. 195; 7, c. 261]. The main directions of its activities that addressed to businesses and individuals are to provide:

1. Information and consulting services are consist in: organization of trainings and internships throughout of sector of issues of development and management of innovative entrepreneurship [11, c. 197-198]; promoting of registration and legal protection of objects of intellectual; attracting of financial institutions in order to implement innovative business projects in the form of grants, seed and venture capital investments; conducting marketing research at any stage of the implementation of innovative business project; promoting of organization and implementation of technology transfer, commercialization of research and development works in order.

2. Scientific-innovation and industrial service that consists in: an organization, promoting and participating in the implementation of applied scientific research and development works; performance of engineering, technological and industrial works on prototype creation and/or sample of innovative product/service [10, c. 20].

The institutes of innovative development of hub can be the center of technology transfer, laboratory base, innovative and technological center, training center for preparation an innovative managers, coaching center of systems of venture entrepreneurship, the center of collective use of technology, design center, information center, logistic center, international business center, venture fund, expocenter with a permanent international venture platform, congress center.

Stages of becoming of innovative hubs, tools and mechanisms of their support are presented in Table 1.

Notable examples of effective work of innovative hubs can be observed in different countries. For example, successful innovative hub is created in the USA by Georgia Institute of Technology, titled "Knowledge Hub" [15].

It is launched the innovative hub "API Moscow" at Moscow School of Management Skolkovo in Russia in 2014. It activity is aimed to support innovative high-tech projects and early stage companies that specialize in the creation of technologies for improving the urban environment. 
К.М. Краус. Інноваційні хаби як площадки економічного росту: закордонний досвід та нові можливості для України

Table 1 - Stages of becoming of innovative hubs, tools and mechanisms of their support (development by author)

\begin{tabular}{|l|l|}
\hline \multicolumn{1}{|c|}{ Steps for creating an innovative hubs } & \multicolumn{1}{|c|}{ Tools and mechanisms of support for innovative hubs } \\
\hline $\begin{array}{l}\text { 1. Information and consulting support from the foundation } \\
\text { of entrepreneurship, innovative center, training } \\
\text { programs, international centers of innovations }\end{array}$ & $\begin{array}{l}\text { Implementation of the stage according to innovative chain of } \\
\text { type: Informing - Training - Consulting - Crash tests of ideas - } \\
\text { Registration of the project - Patenting and prototyping }\end{array}$ \\
\hline $\begin{array}{l}\text { 2. Financing from funds of entrepreneurship and } \\
\text { investments, international and regional innovative } \\
\text { centers }\end{array}$ & $\begin{array}{l}\text { Grants; collateral for loans; back loans; soft loans; venture } \\
\text { financing; subsidizing of lease payments }\end{array}$ \\
\hline $\begin{array}{l}\text { 3. Establishment of industrial service, placement and } \\
\text { direct activity of hubs, technical and technological } \\
\text { support }\end{array}$ & $\begin{array}{l}\text { Implementation of the stage according to innovative chain of } \\
\text { type: land - industrial premises - office premises - business } \\
\text { incubators, innotehy, hackathons - technoparks, industrial parks }\end{array}$ \\
\hline $\begin{array}{l}\text { 4. Development of hubs by an active participation of } \\
\text { educational programs, innovative center and fund for } \\
\text { entrepreneurship support }\end{array}$ & $\begin{array}{l}\text { Establishment of business contacts; participation in exhibitions; } \\
\text { support for export; development of energy efficiency; industrial } \\
\text { cooperation; collaboration in the intellectual sphere }\end{array}$ \\
\hline
\end{tabular}

The first innovative hub in Eastern Europe with program funding of $€ 4$ million began working in Poland in 2014. The initiators of the project are a non-profit organization Start-Up Hub Poland (SHP), Polish National Center for Research and Development (PCR\&D) and Giza Polish Ventures (GPV). The purpose of the hub is attraction for innovative activity on a common technological platform to researchers, inventors, nnovators, and innovators from Central and Eastern Europe, which would strengthen innovative glocalization and innovatization countries in the region.

Existing types of hubs in the world, their differences and characteristics are presented in Table 2.

Table 2 - Types of innovative hubs and their features (generalized by the author based on sources $[2,6,9,11]$ )

\begin{tabular}{|l|l|l|}
\hline \multicolumn{1}{|c|}{ Types of hubs } & \multicolumn{1}{|c|}{ Characteristic features } & \multicolumn{1}{c|}{ Examples } \\
\hline Hub Studio & It is a small niche creative space & $\begin{array}{l}\text { Successfully working in Austria } \\
\text { (Coworking Salzburg) }\end{array}$ \\
\hline Hub Center & It is a powerful and middle in physical space & $\begin{array}{l}\text { In the Netherlands in place of former } \\
\text { Philips factory operates the hub center } \\
\text { Strijp-S }\end{array}$ \\
\hline Hub Cluster & $\begin{array}{l}\text { Include network of analytical and educational centers, } \\
\text { coworking, the association of major companies that } \\
\text { operate in the same sector; they are large in } \\
\text { geographical space and can cover several regions } \\
\text { within the country }\end{array}$ & $\begin{array}{l}\text { Successful is the hub cluster Brighton } \\
\text { Fuse in the UK }\end{array}$ \\
\hline Hub Association & $\begin{array}{l}\text { Not always branched in space, but is based in the same } \\
\text { geographical zone }\end{array}$ & $\begin{array}{l}\text { Effectively working the hub association in } \\
\text { Portugal - ADDICT }\end{array}$ \\
\hline
\end{tabular}

Hubs-studios, which are small niche creative space, are successfully working in Austria (e.g., Coworking Salzburg). Hubs-centers are powerful and average in physical space. For example, in Netherlands on the former Philips factory operates the hub-center Strijp-S.

Hab-clusters include network of analytical and educational centers, coworking, and associations of large companies that operate in the same industry. That is, hub-clusters are large in geographical space and can cover several regions within the country. Felicitous foreign example is the hub-cluster Brighton Fuse in the UK. Hub-associations do not always are branched out into space and always based in the same geographical area. Effectively working hub-association is in Portugal - ADDICT.

Hubs-studios, which are small niche creative space, are successfully working in Austria (e.g., Coworking Salzburg). Hubs-centers are powerful and average in physical space. For example, in 
Netherlands on the former Philips factory operates the hub-center Strijp-S.

Hab-clusters include network of analytical and educational centers, coworking, and associations of large companies that operate in the same industry. That is, hub-clusters are large in geographical space and can cover several regions within the country. Felicitous foreign example is the hub-cluster Brighton Fuse in the UK. Hub-associations do not always are branched out into space and always based in the same geographical area. Effectively working hub-association is in Portugal - ADDICT.

Innovative economy annually provides to the EU about $7 \%$ of GDP or $€ 800$ billion and around 14 million jobs. The European network of creative business (European Creative Business Network ECBN) has invited from European Commission $€ 50$ million for creation of cultural and creative hubs for 2016-2020 years.

Most of hubs and coworking centers that work in Ukraine are private. There are about 200 coworking today in Ukraine. Some of them have become platforms for meetings of start-up. It is felicitous the Kyiv Kovorkin Center "Chasopys" based on which are conducted business trainings, workshops, educational lectures, conferences, competitions in the field of innovations.

Cabinet of Ministers approved a decree on the national project "Technopolis" in 2012, which involves construction of innovative parks in Kyiv, Kharkiv, Lviv and Dnipro and creation of 70-75 thousand jobs for professionals in sphere of IT, biotechnology, energy, nanotechnology. Ukrainian "Silicon Valley" was to be an innovative park Bionic Hill, whose construction is planned in Kyiv. But the project is suffered a setback due to the lack of appropriate government and financial support.

It can be considered today as successful activity of the association "Innovative development of Ukraine" which contributes to implementation of promising Ukrainian innovative projects and works on a bill on industrial parks and providing benefits to their members. It was announced in 2015 the opening of innovative center California in Ukraine in Kiev. In premises on the Khreshchatyk Str., which are provided for use by Kiev Administration, are conducted workshops on implementation of innovative projects and hackathons.

Efficiently functioning in Ukraine network of centers for support of innovations and entrepreneurship called iHUB. iHUB initiated by the global network of national nonprofit funds Seed Forum in 2014. iHUB operates supported by the Ministry of Foreign Affairs of Norway and Royal Norwegian Embassy in Kiev, additionally financing by institutions of Finland, Sweden and England.

From grant funds iHUB pays rent and pays for work of scientific staff in Kyiv, Chernihiv, Lviv, Vinnytsia, Ivano-Frankivsk, where there are a number of structural centers as part of public-private partnership of iHUB. In structural centers already employs over 50 experts from 20 countries in 40 areas of educational and innovative events. iHUB is investing in reconstruction, technology and management of projects takes care of all operational and financial risks during the whole period of partnership. Experts estimate that about 20 thousand of people were interested in this project and became its participants in order to obtain knowledge to create start-ups [2].

On the basis of innovative hub for its participants must be mentoring programs, workshops from experts of business schools, special meetings with venture companies, consultations from marketers, lawyers and financiers concerning business support [7, c. 266]. The task of innovative hub should be to create favorable conditions for development of innovative projects that improve quality of life. For this reason, innovative projects of hub must be characterized by opportunities in new ways to solve problems of ecological character and key economic sectors (transport, health, energy, utilities and education) [9, c. 322].

Now we can observe the distribution of world practice of creation of clusters in Ukraine, which is due to support of international EU project "Support of Sustainable Regional Development"; Coordinator of Projects of OSCE in Ukraine; The US Agency for International Development (USAID); Ukrainian-German project "Promoting economic development and employment" with the participation of German Society for Technical Cooperation in Ukraine, that provide informational and expert support of cluster development in its formative stages of cluster initiatives.

These data confirm the interest of different kinds of institutions, organizations and agencies in the creation of regional business networks and ensuring reliable platform for the formation of cluster policy at 
the state level. Currently, the vast majority of Ukrainian clusters, whose number according to various estimates reaches 50 , are in their infancy.

The most popular for their creation is the field of tourism, food and engineering industries, while high technology (electronics, alternative energy, nanotechnology and pharmaceuticals) are presented few. Clustering leader in high technology are available organizations that perform scientific and technical works in Kharkiv region and in Kyiv.

The pioneer of clustering in Ukraine is Khmelnytskyi region, where there are more than 10 years building and sewing clusters, and in 2002 launched the first in Ukraine tourism cluster "Oberih", designed as a public organization. This organization includes more than 50 representatives of agricultural companies, farmers, fishermen and masters of folk trades.

In Zaporizhzhia region successfully operates Machinery cluster LLC "AhroBum". He includes more than 20 companies and develops cooperation on the principles of subcontract. In Ivano-Frankivsk region there is Tysmenytsya fur cluster on the basis of OJSC "Fur Company Tysmenytsia". In Rivne region there is woodworking cluster "Polissia of Rokytne region" that created in 2003 [4, c. 26].

A promising direction for Ukraine is the creation of cross-border clusters. Considering that 19 of 25 regions are borderline, Ukraine has all opportunities for cooperation with foreign companies within the cross-border clusters. Example of such cooperation is the Ukrainian-Romanian "First Agrarian Cluster" created in 2009 in Chernivtsi region. Within the framework of Programme of Transboundary Cooperation Poland - Belarus - Ukraine for 2007-2013 is formed Ukrainian-Polish tourist-recreational cluster [4, c. 27].

In the context of our research let us give example an innovative construction cluster in Poltava region as spatially localized association of participants of investment and construction processes, innovative enterprises of building materials industry and other related sectors to construction, research institutes, universities, banks and other credit institutions, public organizations and local governments in order to improve competitiveness of construction products and growth of the region as a whole.

It is connected to the fact that building complex is one of the most important components of the economy of the country. Effective functioning of this complex is the precondition of perspective development of the economy. Today we can see that the crisis in the global and Ukrainian economy significantly slowed the development of the construction. The critical situation exists at the regional level, particularly in Poltava region.

Among the main factors slowing the dynamics of building complex in Poltava region are: substantial currency fluctuations, liquidity crisis of banks, reducing of domestic effective demand of population. Providing output of construction industry from crisis economic conditions and possible future development in the implementation of new forms of relations between industry, government, public institutions, and universities in particular through formation of construction cluster based on innovative hub.

The basic principle of construction of innovative hub is the choice of directions of scientific, technical and technological development of economy of Poltava region considering its scientific and innovative potential. The model of regional innovative system based on hubs allows create conditions for effective integration of real, financial and scientific sectors of socio-economic system. Main advantage of innovative hub of the construction industry in this context is that it allows effectively using the innovative potential of Poltava region, stimulating the development of innovative business that provides increase of level and quality of population life within the concept of an innovative economy.

Today there are all prospects and opportunities to create innovative hub for construction sector in Poltava region, namely:

- Availability of affordable high quality raw materials for production of building materials directly in Poltava region;

- Sufficient number of enterprises (2,500 units) based on which can be tested and implemented innovative projects;

- Understanding of the problems, will and desire of leadership of the region and all the participants to join efforts for the achievement strategic goals and the presence in the southeast region and beyond its 
borders substantial, economically reasonable needs and demand for innovative products of cluster;

- Effectively working research centers that provide a fundamental scientific basis for innovative ideas and projects (Poltava Gravimetric Observatory, Poltava Branch UkrDGRI, Branch of Northeast Science Center);

- Import of products construction materials industry from neighboring regions (Kharkiv, Dnipropetrovsk, Zaporizhzhya) and other countries;

- Signed on 12 October 2012 an agreement about the intentions establish a joint research park "Energy efficient technologies" Poltava National Technical University of Y. Kondratyuk with Khmelnytskyi National University, Ivano-Frankivsk National Technical University of Oil and Gas and SHEE "National Mining University". To date, the Ministry of Education and Science of Ukraine officially supports work in this direction (Letter № 1/ 11-19266 of 13 December 2012);

- Affordable housing prices (using its own natural resources, geographical concentration of production will allow to reduce construction costs and to increase its quality characteristics);

- The existence of network of universities and vocational schools for the production of professionals of building and economic fields. In particular, in Poltava is located Poltava National Technical University of $Y$. Kondratyuk that carries out preparation of highly qualified specialists in the construction, architectural, electromechanical faculties, prepares future workers in information and telecommunication technologies and systems. Poltava University of Economics and Trade prepares specialists in the areas of training Documentation and Information activity, Marketing (specialty: Marketing, Advertising Business, Business Logistics), Finance and Credit (specialty: Finances of Enterprise, Banking, Investment Activity, Insurance Business), Biotechnology, Accounting and Audit.

Prior to construction cluster in Poltava region must include all participants in the investment-building complex. Among the investment and construction companies, which we believe must to join the cluster is the first, large building and assembly organizations that have the experience, reputation and steadily get large profit. We believe that there is an effective inclusion to cluster 3-4 of investment and construction companies that focused for implementation of separate investment projects.

It is necessary to noted that this innovative hub of construction cluster is node for support high traffic innovations, through which passes all logistics of innovative development of region. Innovative hub of this kind will help to create regional innovative markets, to provide dominant presence on them, to organize flow of capital (primarily venture), to set "rules of the game", to determine norms of relations between subjects and to form creative and innovative focused talent pool. Innovative hub will facilitate quickly and efficiently integrated "rework" of innovations (as ideas) into innovative products, which are successfully implemented on high-tech markets of region [1, c. 278].

The main advantage of our proposed clustering approach based on innovative hub consists in the fact that through such development of cluster systems higher education can effectively integrate results of university, academic and sectoral science of Ukraine [12], as well as advanced results of science of world community in the development and implementation of innovative projects.

Conclusions. Formation of institutional environment based on clustering provides a powerful impetus for an effective innovative economy on condition of an integrated modernization. The present stage of modemization should include primarily large-scale renovation of production influenced the formation of advanced VI-th technological structure. Due to the instability, the extreme variability of the basic elements of Ukrainian society and the presence of residual effects of previous development, before the government of the country there are fundamentally new tasks that it should decide during the institutional transformation.

Future research. "Triple helix", more precisely collaboration of three types of participants of "innovative game" that represent science, business and state has for Ukraine critical importance for formation and establishment of innovative economy. In our further scientific works we are going to prove the necessity of creating in Ukraine industrial innovative hub that based on knowledge, potential of the country and determining possible instruments its support. We are planning to investigate the activities of 
the existing in the world hubs, clusters, innovative centers and studios, and we predict learn informational, consulting, scientific and industrial services that calling carried out by innovative hub.

1. Бібен Ю. М. Кластерна стратегія інноваційного розвитку економіки на мікрорівні: регіональний аспект / Ю. М. Бібен, Н. М. Краус // Вісник Хмельницького національного університету. Серія: Економічні науки. - 2012. - № 1. - С. $277-280$.

2. Власенко В. У пошуках Кремнієвої долини: як держава розвиває інноваційні хаби [Електронний ресурс] В. Власенко // Українська правда. Економічна правда: веб-сайт. - К., 12.08.2015. - Режим доступу: http://www.epravda.com.ua/publications/2015/08/12/554568/.

3. Домбровский М. А. Методологические проблемы экономической кластеризации / М. А. Домбровский // Проблемы современной экономики. - 2011. - № 2. - С. 241-245.

4. Інноваційні підходи до регіонального розвитку в Україні: аналіт. доп. / С. О. Біла, Я. А. Жаліло, О. В. Шевченко, В. І. Жук [та ін.]; за ред. С. О. Білої. - К. : НІСД, 2011. - 80 с.

5. Краус Н.М. Вплив інноваційної глобалізації на інноваційну глокалізацію економіки України крізь призму інституціоналізму та колаборації [Електронний ресурс] / Н. М. Краус // Глобальні та національні проблеми економіки. 2016. - № 9. - Режим доступу: http://www.global-national.in.ua.

6. Краус Н. М. Інноваційні хаби як основа конкурентоспроможної економіки: закордонний вимір та уроки для України [Електронний ресурс] / Н. М. Краус // Конкурентоспроможність національної економіки: зб. тез XV Міжнар. наук.-практ. конф., 26-27 берез. 2015 р., м. Київ. - Електрон. текст. дані. - К. : [б. в.], 2015. - С. 193-198.

7. Краус Н. М. Інституціональна проекція інноваційного хабу в рамках побудови конкурентоспроможної національної економіки / Н. М. Краус // Теоретичні та прикладні питання економіки : зб. наук. пр. Київ. нац. ун-ту ім. Тараса Шевченка. 2015. - № 30. - С. 259-270.

8. Краус Н. М. Інституціональні аспекти кластеризації в інноваційній економіці під впливом системної та комплексної модернізації / Н. М. Краус // Економічний часопис - XXI. - 2014. - № 5-6. - С. 29-32.

9. Краус Н. М. Становлення інноваційної економіки в умовах інституціональних змін: монографія / Н. М. Краус. - Київ: Центр учбової л-ри, 2015. - 596 с.

10. Программа "ЭВРИКА". Комплексная система развития научно-исследовательских, опытно-конструкторских и технологических работ в вузе. Кейс Санкт-Петербургского национального исследовательского университета информационных технологий, механики и оптики (НИУ ИТМО) - пилотного университета программы: ресурсный сб. / под ред. В. Н. Васильева, Н. Р. Тойвонена; Некоммерческая организация Фонд “Новая Евразия”. - СПб. : [б.и.], 2012. - 176 с.

11. Baark E., Naubahar Sh. From Trade Hub to Innovation Hub: The Role of Hong Kong's Innovation System in Linking China to Global Markets / E. Baark, Sh. Naubahar // Innovation: Management, Policy \& Practice, V. 8, No 1-2, April 2006. - P. $193-209$.

12. Gorzka G. Knowledge Transfer. The New Core Responsibility of Higher Education Institutions Practice and Perspectives in Russia and Germany. - UniKasselTransfer. Ost- West-Wissenschaftszentrum. - 2012, kassel university press GmbH, Kassel. $244 \mathrm{p}$.

13. OECD Science, Technology and Industry Outlook 2014 [Electronic resource]. - Publication date: 12 Nov. 2014. - 478 p. Mode of access: http://www.oecd-ilibrary.org/science-and-technology/oecd-science-technology-and-industry-outlook2014_sti_outlook-2014-en.

14. OECD (2013), OECD Reviews of Innovation Policy: Sweden 2012, OECD Publishing [Electronic resource]. - Mode of access: http://www.keepeek.com/Digital-Asset-Management/oecd/science-and-technology/oecd-reviews-of-innovation-policysweden-2012_9789264184893-en\#page7.

15. Youtie J. Building an Innovation Hub: A Case Study of the Transformation of University Roles in Regional Technological and Economic Development / J. Youtie, Ph. Shapira // Research Policy. - 2008. - Vol. 37, Issue 8. - P. 1188-1204.

1. Biben, Yu. M. \& Kraus, N. M. (2012). Klasterna stratehiia innovatsiinoho rozvytku ekonomiky na mikrorivni: rehionalnyi aspekt [Cluster strategy of innovative development of economy at the micro level: regional aspect]. Visnyk Khmelnytskoho natsionalnoho universytetu. Seriia: Ekonomichni nauky - Journal of Khmelnytsky National University. Serie: Economic Sciences, 1 , 277-280 [in Ukrainian].

2. Vlasenko, V. (2015). U poshukakh Kremniievoi dolyny: yak derzhava rozvyvaie innovatsiini khaby [In search of Silicon Valley: as a state develops innovative hubs]. Ukrainska pravda. Ekonomichna pravda: veb-sait - Ukrainian Truth. Economic Truth: Website. Retrieved from http://www.epravda.com.ua/publications/2015/08/12/554568/ [in Ukrainian].

3. Dombrovskiy, M. A. (2011). Myetodologichyeskiye problyemy ekonomichyeskoy klastyerizatsii [Methodological problems of economic clustering]. Problyemy sovryemyennoy ekonomiki - Problems of Modern Economy, 2, 241-245 [in Russian].

4. Bila, S. O., Zhalilo, Ya. A., Shevchenko, O. V. \& Zhuk, V. I (2011). Innovatsiini pidkhody do rehionalnoho rozvytku v Ukraini [Innovative approaches to the regional development in Ukraine]. Kyiv: NISD [in Ukrainian].

5. Kraus, N.M. (2016). Vplyv innovatsiinoi hlobalizatsii na innovatsiinu hlokalizatsiiu ekonomiky Ukrainy kriz pryzmu instytutsionalizmu ta kolaboratsii [The impact of innovative globalization on innovative glocalization Ukraine's economy through the prism of institutionalism and collaboration]. Hlovalni ta natsionalni problem ekonomily - Global and National Economic Problems, 9. Retrieved from http://www.global-national.in.ua [in Ukrainian].

6. Kraus, N.M. (2015). Innovatsiini khaby yak osnova konkurentospromozhnoi ekonomiky: zakordonnyi vymir ta uroky dlia 
Ukrainy [Innovation hubs as the basis of a competitive economy: international dimension and experience for Ukraine]. Proceedings of the XV International Conference '15: XV Mizhnarodna naukovo-praktychna konferentsiia "Konkurentospromozhnist natsionalnoi ekonomiky" - The XV International Scientific and Practical Conference "The competitiveness of national economy". (pp. 193-198). Kyiv [in Ukrainian].

7. Kraus, N.M. (2015). Instytutsionalna proektsiia innovatsiinoho habu v ramkah pobudovy konkurentospromozhnoi natsionalnoi ekonomiky [Institutional projection of innovative hub within the construction of competitiveness national economy]. Teoretychni ta prykladni pytannia ekonomiky - Theoretical and Applied Problems of Economy: Proceedings of the scientific papers, 30, (pp. 259-270). Kyiv: KNU by Taras Shevchenko [in Ukrainian].

8. Kraus, N.M. (2014). Instytutsionalni aspekty klasteryzatsii v innovatsiinii ekonomitsi pid vplyvom systemnoi ta kompleksnoi modernizatsii [Institutional aspects of clustering in innovative economy under the influence of systemic and comprehensive modernization]. Ekonomichnyi chasopys - XXI - Economic Annals - XXI, 5-6, 29-32 [in Ukrainian]

9. Kraus, N.M. (2015). Stanovlennia innovatsiinoi ekonomiky $v$ umovakh instytutsionalnykh zmin [The formation of innovative economy in conditions of institutional changes]. Kyiv: Center of Educational Literature [in Ukrainian].

10. Vasiltev, V. N. \& Toyvonen, N. R. (2012). Programa "Evrika". Komplyeksnaya sistyema pazvitiya nauchnoisslyedovatyelskikh, opytno-konstruktorskikh I tyekhnologichyeskikh rabot $v$ vuzye ["EUREKA" program. Complex system of the development of scientific and research, experimental, design and technological works in the university]. St. Petersburg: Nonprofit organization Fund "New Eurasia" [in Russian].

11. Baark, E. \& Naubahar, Sh. (2006). From Trade Hub to Innovation Hub: The Role of Hong Kong's Innovation System in Linking China to Global Markets. Innovation: Management, Policy \& Practice, 8 (1-2), 193-209.

12. Gorzka, G. (2012). Knowledge Transfer. The New Core Responsibility of Higher Education Institutions Practice and Perspectives in Russia and Germany. Kassel: Kassel University Press GmbH.

13. OECD Science, Technology and Industry (2014). www.oecd-ilibrary.org. Retrieved from http://www.oecd-ilibrary.org/science-andtechnology/oecd-science-technology-and-industry-outlook-2014_sti_outlook-2014-en.

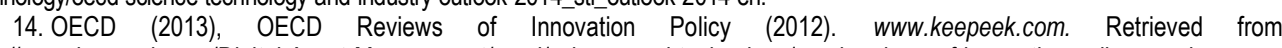
http://www.keepeek.com/Digital-Asset-Management/oecd/science-and-technology/oecd-reviews-of-innovation-policy-sweden2012_9789264184893-en\#page7. Sweden: OECD Publishing.

15. Youtie, J. (2008). Building an Innovation Hub: A Case Study of the Transformation of University Roles in Regional Technological and Economic Development. Research Policy, 37 (8), 1188-1204.

К.М. Краус, к.е.н., доцент кафедри комерційної діяльності та підприємництва ВНЗ Укоопспілки «Полтавський університет економіки і торгівлі» (Полтава, Україна)

Інноваційні хаби як площадки економічного росту: закордонний досвід та нові можливості для України

у статmі описано загальні особливості сучасних інноваційних кластерів світу. З'ясовано суть інноваційного хабу та розглянуто основні напрями його діяльності на сучасному етапі економічного розвитку. Виявлено ряд інститутів, що сприяють інноваційному розвитку хабів. Узагальнено місце та роль сучасних хабів-студій, хабів-центрів, хабівкластерів та хабів-асоціацій в країнах Західної Європи. Досліджено ключові фрактори успіху діяльності мережі центрів підтримки інновацій і підприємництва (iHUB) в Україні, виявлено їі головних міжнародних партнерів, завдання та напрями діяльності. Розглянуто та обгрунтовано перспективи створення в Україні прикордонних кластерів. Досліджено діяльність інноваційного будівельного кластера в Полтавському регіоні, виявлено його учасників, основні завдання та стримуючі чинники розвитку.

Ключові слова: інноваційний хаб, кластер, інститути інноваційного розвитку, хаб-студія, хаб-центр, хаб-асоціація, будівельний кластер.

Е.Н. Краус, к.э.н., доцент кафедры коммерческой деятельности и предпринимательства ВУз Укоопсоюза «Полтавский университет экономики и торговли» (Полтава, Украина)

Инновационные хабы как площадки экономического роста: зарубежный опыт и новые возможности для украины

В статье описано общие особенности современных инновационных кластеров мира. Выяснено суть инновационного хаба и рассмотрено основные направления его деятельности на современном этапе экономического развития. Выявлен ряд институтов, способствующих инновационному развитию хабов. Обобщенно место и роль современных хабов-студий, хабов-центров, хабов-кластеров и хабов-ассоциаций в странах Западной Европы. Исследовано ключевые фракторы успеха деятельности сети центров поддержки инноваций и предпринимательства (iHUB) в Украине, выявлено ее главных международных партнеров, задачи и направления деятельности. Рассмотрено и обосновано перспективы создания в Украине приграничных кластеров. Исследована деятельность инновационного строительного кластера в Полтавском регионе, выявлены его участники, основные задачи и сдерживающие факторы развития.

Ключевые слова: инновационный хаб, кластер, институты инновационного развития, хаб-студия, хаб-центр, хабассоциация, строительный кластер.

Отримано 22.11.2016 p. 